MATERIALS

\title{
Relative Variability in Body Dimensions of Punjabi Infants Longitudinally Examined during the First Year of Life
}

\author{
A.K. BHALlA and B.N.S. WALiA \\ Department of Pediatrics, Post Graduate Institute of Medical Education and \\ Research, Chandigarh, India
}

\begin{abstract}
Serial data depicting relative variability of sixteen (nine absolute and seven generated) body dimensions of 154 Punjabi infants from Chandigarh, India are presented. Coefficients of variation (CV) were computed for the body measurements at monthly age intervals so as to compare age to age variability encountered in different body dimensions during infancy. Summary coefficients were used for assessment of the magnitude of variability between different measurements. Comparison of data at different age periods showed least variability in values of head circumference in contrast to other body dimensions. Relatively higher values for variability were recorded for skinfold thicknesses. Log transformed skinfold measurements showed lower degree of variability in contrast to same untransformed measurements.
\end{abstract}

Keywords Punjabi infants, Body dimensions, Relative variability, Coefficient of Variation, Summary coefficient

\section{Introduction}

In order to understand dynamics of human growth, it is essential to understand the concept of variability as applied to different body measurements used for assessment of growth status of individuals or groups of subjects. In majority of publications, mean trends of growth have been presented accompanied by variability statistics. In most of these reports, no attempt was made to quantify the magnitude of variability around means of measurements over a period of time and their relative importance to each other. MEREDITH (1935) and BOYNTON (1936) opined that coefficient of variation is more meaningful than standard deviation in order to compare the variability of any or all measurements.

In the present study, a comparison was made of the measurement to measurement and age to age variability in terms of coefficient of variation for 16 body dimensions during the first year of life.

\section{Subjects and Methods}

One hundred and fifty four (86 males and 68 females) infants of Punjabi parentage belonging to mixed socio-economic strata and residing in Chandigarh (India) comprised the sample for this serial study. Every child included in the study was normal, healthy, full-termed and weighed more 
than $2,500 \mathrm{~g}$ at birth.

Nine parameters (body weight, crown-heel length, head circumference, chest circumference, calf circumference and triceps, mid-axillary and subscapular skinfold thickness) were measured in every child at monthly age levels with a time tolerance of \pm 3 days on the day of measurement during the first year of life. Besides the nine basic measurements, seven transformations were generated from these measurements for each child at all the monthly age levels. These include (1) sum of skinfolds (triceps + mid-axillary + subscapular), (2) log transformation of triceps skinfold, (3) log transformation of mid-axillary skinfold, (4) log transformation of subscapular skinfold, (5) sum of log transformed skinfolds (triceps, subscapular and mid-axillary), (6) corrected upper arm diameter and (7) mid-upper arm-muscle circumference. The corrected upper arm diameter was calculated by using the formula given by BROZEK (1956):

$$
\mathrm{D}=\mathrm{C} / \pi-\mathrm{S}
$$

where $\mathrm{D}$ is the corrected diameter, $\mathrm{C}$ the circumference of upper arm, $\pi$ equals 3.1415 and $\mathrm{S}$ stands for the triceps skinfold thickness. The mid-upper arm-muscle circumference was calculated by applying the formula given by JELLIFFE and JELLIFFE (1960):

$$
\mathrm{C}_{2}=\mathrm{C}_{1}-\pi \mathrm{S}
$$

where $C_{2}$ is mid-upper arm-muscle circumference, $C_{1}$ stands for upper arm circumference, $\pi$ equals 3.1415 and $S$ indicates triceps skinfold measurement. Log transformations of skinfold thicknesses were done by applying the formula given by EDWARDS et al. (1955):

$Z=100 \log _{10}$ (reading in $0.1 \mathrm{~mm}-18$ )

Only three body measurements, crown-heel length, body weight and head circumference were taken on every child within 24 hours of the birth while remaining measurements were taken between 1 and 12 months of age. The monthly follow up of all the babies was carried out in the growth clinic and neonatal follow up clinic attached respectively to the Departments of Community Medicine and Pediatrics of the Post Graduate Institute of Medical Education and Research, Chandigarh. A detailed account of the subjects used, the follow up schedule, sampling and measurement techniques used along with the basic data have been given elsewhere (BHALLA, 1983).

Conventional statistics were used to calculate central tendency and variability statistics including coefficient of variation (CV) for each measurement at monthly age levels. A single coefficient of variation termed as summary coefficient (MEREDITH, 1935) was calculated so as to make a general comparison between different body dimensions. This is expressed as an average of CV values calculated for every body measurement at each monthly age interval.

\section{Results and Discussion}

Summary coefficients, computed for each body measurement ( 9 absolute and 7 generated measurements) between 1 and 12 months of age for male and female infants arranged in increasing order are given in Table 1. Whereas, age to age variability for different body dimensions among male and female infants is given in Tables 2 and 3 , respectively.

Head circumference is the least variable of all the 16 body measurements ( 9 absolute and 7 generated). It is about $75 \%$ in male and $85 \%$ in female as variable as crown-heel length, $61 \%$ in male and $67 \%$ in female as variable as chest circumference, $41 \%$ as variable as calf circumference in male and $46 \%$ in female, and $36 \%$ and $40 \%$ as variable as arm circumference in male and female infants, respectively. The magnitude of variability for head circumference was found to be about $15 \%$ in male and $17.5 \%$ in female infants when compared with the sum of three absolute skinfold measurements (Table 1). 
Table 1. Summary coefficients for different body measurements in Punjabi male and female infants

\begin{tabular}{|c|c|c|c|}
\hline \multicolumn{2}{|l|}{ Males $(\mathrm{N}=86)$} & \multicolumn{2}{|l|}{ Females $(\mathrm{N}=68)$} \\
\hline Measurement & $\begin{array}{l}\text { Summary } \\
\text { coefficient }\end{array}$ & Measurement & $\begin{array}{l}\text { Summary } \\
\text { coefficient }\end{array}$ \\
\hline Head circumference & 2.8 & Head circumference & 3.2 \\
\hline Crown-heel length & 3.7 & Crown-heel length & 3.8 \\
\hline Chest circumference & 4.6 & Chest circumference & 4.8 \\
\hline Calf circumference & 6.8 & $\begin{array}{l}\text { Triceps skinfold (log } \\
\text { transformed) }\end{array}$ & 6.1 \\
\hline $\begin{array}{l}\text { Sum of three log } \\
\text { transformed skinfolds } \\
\text { (Triceps }+ \text { Mid-axillary }+ \\
\text { Subscapular) }\end{array}$ & 6.9 & $\begin{array}{l}\text { Sum of three log } \\
\text { transformed skinfolds } \\
\text { (Triceps + Mid-axillary+ } \\
\text { Subscapular) }\end{array}$ & 6.9 \\
\hline $\begin{array}{l}\text { Subscapular skinfold } \\
\text { (log transformed) }\end{array}$ & 7.1 & Calf circumference & 7.0 \\
\hline $\begin{array}{l}\text { Corrected upper arm } \\
\text { diameter }\end{array}$ & 7.5 & $\begin{array}{l}\text { Subscapular skinfold } \\
\text { (log transformed) }\end{array}$ & 7.7 \\
\hline $\begin{array}{l}\text { Mid-upper arm-muscle } \\
\text { circumference }\end{array}$ & 7.5 & Arm circumference & 8.0 \\
\hline $\begin{array}{l}\text { Triceps skinfold } \\
\text { (log transformed) }\end{array}$ & 7.7 & $\begin{array}{l}\text { Mid-axillary skinfold } \\
\text { (log transformed) }\end{array}$ & 8.7 \\
\hline Arm circumference & 7.9 & $\begin{array}{l}\text { Mid-upper arm-muscle } \\
\text { circumference }\end{array}$ & 8.8 \\
\hline $\begin{array}{l}\text { Mid-axillary skinfold } \\
\text { (absolute) }\end{array}$ & 8.7 & $\begin{array}{l}\text { Corrected upper-arm } \\
\text { diameter }\end{array}$ & 8.8 \\
\hline W eight & 12.2 & Weight & 12.0 \\
\hline $\begin{array}{l}\text { Sum of three absolute } \\
\text { skinfolds (Triceps }+ \\
\text { Mid-axillary }+ \text { Subscapular }\end{array}$ & 18.3 & $\begin{array}{l}\text { Sum of three absolute } \\
\text { skinfolds (Triceps }+ \\
\text { Mid-axillary }+ \text { Subscapular) }\end{array}$ & 18.3 \\
\hline $\begin{array}{l}\text { Subscapular skinfold } \\
\text { (absolute) }\end{array}$ & 19.4 & $\begin{array}{l}\text { Triceps skinfold } \\
\text { (absolute) }\end{array}$ & 19.3 \\
\hline $\begin{array}{l}\text { Triceps skinfold } \\
\text { (absolute) }\end{array}$ & 21.8 & $\begin{array}{l}\text { Subscapular skinfold } \\
\text { (absolute) }\end{array}$ & 20.9 \\
\hline $\begin{array}{l}\text { Mix-axillary skinfold } \\
\text { (absolute) }\end{array}$ & 21.9 & $\begin{array}{l}\text { Mid-axillary skinfold } \\
\text { (absolute) }\end{array}$ & 21.1 \\
\hline
\end{tabular}


Table 2. Coefficients of variation in Punjabi male infants

\begin{tabular}{|c|c|c|c|c|c|c|c|c|c|c|c|c|c|}
\hline \multirow[b]{2}{*}{ Measurement } & \multirow[b]{2}{*}{ Birth } & \multirow[b]{2}{*}{1} & \multirow[b]{2}{*}{2} & \multicolumn{4}{|c|}{ Age (months) } & \multirow[b]{2}{*}{7} & \multirow[b]{2}{*}{8} & \multirow[b]{2}{*}{9} & \multirow[b]{2}{*}{10} & \multirow[b]{2}{*}{11} & \multirow[b]{2}{*}{12} \\
\hline & & & & 3 & 4 & 5 & 6 & & & & & & \\
\hline Weight & 11.7 & 12.6 & 11.9 & 11.7 & 12.0 & 12.2 & 12.2 & 12.7 & 13.3 & 12.4 & 11.6 & 11.4 & 12.3 \\
\hline Crown-heel length & 3.3 & 4.3 & 4.1 & 4.1 & 3.8 & 3.8 & 3.8 & 3.6 & 3.5 & 3.5 & 3.6 & 3.5 & 3.4 \\
\hline Head circumference & 3.0 & 3.0 & 2.7 & 2.8 & 2.7 & 2.8 & 2.9 & 2.9 & 2.8 & 2.8 & 2.8 & 2.7 & 2.7 \\
\hline Chest circumference & - & 4.9 & 4.6 & 4.5 & 4.8 & 5.0 & 5.3 & 4.9 & 5.0 & 5.2 & 4.4 & 4.9 & 4.9 \\
\hline Arm circumference & - & 6.7 & 7.4 & 7.1 & 7.4 & 7.1 & 8.3 & 8.8 & 9.0 & 8.4 & 7.7 & 8.0 & 7.8 \\
\hline Calf circumference & - & 6.4 & 6.4 & 6.6 & 6.4 & 6.9 & 7.3 & 7.6 & 7.5 & 7.0 & 6.2 & 6.8 & 6.7 \\
\hline $\begin{array}{l}\text { Triceps skinfold } \\
\text { (absolute) }\end{array}$ & - & 19.9 & 20.1 & 20.4 & 21.8 & 21.4 & 23.6 & 22.7 & 25.0 & 23.5 & 20.7 & 21.3 & 21.8 \\
\hline $\begin{array}{l}\text { Mid-axillary skinfold } \\
\text { (absolute) }\end{array}$ & - & 20.9 & 18.9 & 20.6 & 22.8 & 20.7 & 23.8 & 24.4 & 25.4 & 22.5 & 21.9 & 20.7 & 21.0 \\
\hline $\begin{array}{l}\text { Subscapular skinfold } \\
\text { (absolute) }\end{array}$ & - & 19.8 & 19.2 & 19.2 & 18.4 & 20.1 & 19.8 & 21.0 & 20.2 & 19.4 & 18.9 & 18.4 & 18.6 \\
\hline $\begin{array}{l}\text { Sum of three absolute } \\
\text { skinfolds (Triceps }+ \\
\text { Mid-axillary + Subscapular) }\end{array}$ & - & 17.6 & 16.8 & 17.1 & 17.1 & 17.7 & 18.0 & 20.6 & 21.3 & 19.9 & 18.2 & 18.2 & 17.7 \\
\hline $\begin{array}{l}\text { Triceps skinfold } \\
\text { (log transformed) }\end{array}$ & - & 7.8 & 7.7 & 6.9 & 7.1 & 7.2 & 7.7 & 7.6 & 8.4 & 8.6 & 7.5 & 8.2 & 7.7 \\
\hline $\begin{array}{l}\text { Mid-axillary skinfold } \\
\text { (log transformed) }\end{array}$ & - & 9.3 & 7.3 & 7.3 & 7.9 & 7.7 & 8.7 & 9.3 & 12.9 & 9.1 & 8.8 & 8.6 & 9.0 \\
\hline $\begin{array}{l}\text { Subscapular skinfold } \\
\text { (log transformed) }\end{array}$ & - & 7.8 & 7.1 & 6.2 & 6.2 & 7.0 & 6.9 & 7.1 & 8.0 & 7.5 & 6.8 & 6.8 & 7.2 \\
\hline $\begin{array}{l}\text { Sum of three log transformed } \\
\text { skinfolds (Triceps + Mid- } \\
\text { axillary + Subscapular) }\end{array}$ & - & 7.3 & 6.4 & 5.9 & 5.7 & 6.0 & 6.9 & 7.1 & 8.9 & 7.3 & 6.9 & 7.1 & 7.0 \\
\hline Corrected upper arm diameter & - & 6.9 & 7.4 & 7.4 & 7.8 & 7.1 & 7.0 & 7.9 & 8.0 & 7.6 & 7.4 & 7.3 & 7.7 \\
\hline $\begin{array}{l}\text { Mid-upper arm-muscle } \\
\text { circumference }\end{array}$ & - & 6.9 & 7.4 & 7.4 & 7.8 & 7.1 & 7.0 & 7.9 & 8.0 & 7.6 & 7.4 & 7.3 & 7.7 \\
\hline
\end{tabular}

Corrected upperarm diameter in both male and female infants is equal in variability to midupper arm-muscle circumference.
In comparison to other body measurements examined by us, skinfold measurements showed higher degree of variability. The summary co- 
Table 3. Coefficients of variation in Punjabi female infants

\begin{tabular}{|c|c|c|c|c|c|c|c|c|c|c|c|c|c|}
\hline \multirow[b]{2}{*}{ Measurement } & \multirow[b]{2}{*}{ Birth } & \multirow[b]{2}{*}{1} & \multirow[b]{2}{*}{2} & \multicolumn{4}{|c|}{ Age (months) } & \multirow[b]{2}{*}{7} & \multirow[b]{2}{*}{8} & \multirow[b]{2}{*}{9} & \multirow[b]{2}{*}{10} & \multirow[b]{2}{*}{11} & \multirow[b]{2}{*}{12} \\
\hline & & & & 3 & 4 & 5 & 6 & & & & & & \\
\hline Weight & 11.3 & 13.2 & 11.8 & 11.7 & 11.6 & 11.3 & 12.4 & 12.7 & 12.3 & 12.2 & 12.0 & 11.5 & 11.2 \\
\hline Crown-heel length & 3.3 & 3.5 & 4.0 & 4.1 & 4.0 & 3.6 & 3.5 & 3.8 & 3.7 & 4.3 & 3.8 & 3.7 & 3.5 \\
\hline Head circumference & 2.8 & 3.0 & 3.0 & 3.5 & 3.3 & 3.2 & 3.3 & 3.3 & 3.3 & 3.3 & 3.2 & 3.2 & 3.1 \\
\hline Chest circumference & - & 5.0 & 5.0 & 4.8 & 4.7 & 4.6 & 5.1 & 5.3 & 5.2 & 4.9 & 4.2 & 4.4 & 4.7 \\
\hline Arm circumference & - & 7.9 & 7.9 & 8.5 & 7.3 & 7.0 & 7.6 & 8.0 & 8.7 & 8.1 & 8.1 & 7.8 & 9.2 \\
\hline Calf circumference & - & 6.0 & 7.1 & 8.3 & 8.0 & 8.2 & 6.8 & 7.9 & 7.1 & 6.5 & 6.7 & 5.7 & 5.5 \\
\hline $\begin{array}{l}\text { Triceps skinfold } \\
\text { (absolute) }\end{array}$ & - & 22.8 & 20.2 & 18.7 & 19.0 & 19.5 & 18.0 & 14.9 & 20.3 & 18.1 & 19.4 & 20.5 & 19.2 \\
\hline $\begin{array}{l}\text { Mid-axillary skinfold } \\
\text { (absolute) }\end{array}$ & - & 25.8 & 24.7 & 22.8 & 19.0 & 21.4 & 21.4 & 21.0 & 22.7 & 20.5 & 19.6 & 18.4 & 15.9 \\
\hline $\begin{array}{l}\text { Subscapular skinfold } \\
\text { (absolute) }\end{array}$ & - & 24.8 & 22.6 & 23.0 & 21.1 & 21.7 & 20.1 & 19.2 & 21.0 & 19.3 & 19.4 & 19.2 & 19.7 \\
\hline $\begin{array}{l}\text { Sum of three absolute } \\
\text { skinfold }\end{array}$ & - & 22.3 & 20.1 & 19.4 & 17.5 & 17.8 & 17.4 & 16.5 & 18.5 & 17.4 & 17.8 & 18.9 & 16.8 \\
\hline $\begin{array}{l}\text { Triceps skinfold } \\
\text { (log transformed) }\end{array}$ & - & 12.8 & 7.1 & 6.7 & 6.5 & 6.2 & 6.1 & 5.3 & 6.8 & 6.4 & 6.4 & 6.8 & 6.4 \\
\hline $\begin{array}{l}\text { Mid-axillary skinfold } \\
\text { (log transformed) }\end{array}$ & - & 17.5 & 10.0 & 8.1 & 7.1 & 7.4 & 7.8 & 7.9 & 8.9 & 8.0 & 8.3 & 7.3 & 6.4 \\
\hline $\begin{array}{l}\text { Subscapular skinfold } \\
\text { (log transformed) }\end{array}$ & - & 11.1 & 8.2 & 8.3 & 7.6 & 7.8 & 7.1 & 7.1 & 7.4 & 7.2 & 7.2 & 6.5 & 6.3 \\
\hline $\begin{array}{l}\text { Sum of three log transformed } \\
\text { skinfolds }\end{array}$ & - & 12.7 & 7.5 & 7.0 & 6.2 & 6.1 & 6.2 & 6.1 & 6.9 & 6.5 & 5.7 & 6.3 & 5.7 \\
\hline Corrected upper-arm diameter & - & 9.1 & 9.2 & 9.3 & 8.0 & 8.4 & 8.6 & 8.6 & 9.1 & 8.7 & 8.4 & 8.0 & 10.2 \\
\hline $\begin{array}{l}\text { Mid-upper arm-muscle } \\
\text { circumference }\end{array}$ & - & 9.1 & 9.2 & 9.3 & 8.0 & 8.4 & 8.6 & 8.6 & 9.1 & 8.7 & 8.4 & 8.0 & 10.2 \\
\hline
\end{tabular}

efficients were maximum in the case of midaxillary skinfold thickness showing a value of 21.9 in male and 21.1 in female infants. It is observed in the present study that log transformed skinfold measurements show lower degree of variability when compared with the same untransformed skinfold measurement (Table 1). By transforming into their logs the variability for triceps was lowered by $64.68 \%$ in male and $68.22 \%$ in female infants, for mid- 
axillary $66.0 \%$ in male and $59 \%$ in female and for subscapular, it was found to be slightly more than $63.2 \%$ in both male and female infants. Because of the markedly non-GAUSSIAN frequency distribution of the skinfold measurements, it is recommended to transform absolute skinfold measurements values into their log transformations.

Amongst the other measurements, body weight was observed to experience maximum variation in its distribution (Table 1).

Comparison of age to age variability between birth and 1-12 months of age reveals that of all the body measurements, least variability is experienced by head circumference. Beyond one month of age, values for female infants are found to be throughout greater than those for the male infants of the same age. Like head circumference, crown-heel length also reveals a narrow range of inter-age variability. The two measures of muscle mass, namely, corrected upper arm diameter and mid-upper arm-muscle circumference depict same $\mathrm{CV}$ values at monthly age levels (Tables 2,3 ).

Skinfold measurements in general reveal higher $\mathrm{CV}$ values as compared to other body measurements. The maximum variability for absolute subscapular skinfold thickness in males was recorded at 7 months, while highest figures for both triceps and mid-axillary absolute skinfolds were noticed at eight months of age. The highest values for variability depicted by all the three absolute measures of skinfold thicknesses in female infants were noticed at one month of age (Tables 2, 3). The magnitude of inter-age variability for three skinfold thicknesses was found to be largest as compared to other body dimensions, both in male and female infants.

Age to age comparisons of various body measurements in general, depict an almost consistent trend as no substantial differences in the $\mathrm{CV}$ values for various body measurements are recorded when compared at different age levels among infants of the two sexes (Tables 2, 3). This amply clarifies that, with the advancement of age body dimensions considered here (excluding skinfolds) remain more or less homogeneous in their distribution during the first year of life, which is a period of rapid growth. This cannot be attributed solely to the basic nature of the measurements involved but to several quality control measures instituted during the study span which included; constancy of sample size, homogeneity of racial or sub-racial stocks, strict adherence to time tolerance limits of \pm 3 days on the day of measurements, and use of precise and same instruments throughout the tenure of study. Besides, these all measurements were taken by the same investigator (AKB) throughout the study span.

\section{抄録}

生後一年間の個人追跡による Punjabi 幼児の身体計 測值の変動係数

A. K. Bhalla and B. N. S. Walia

本研究は154名の Punjabi 児童 (Chandigarh, India）の身体計測值からの16の変動係数について述 べている. 生後一年間の幼児期の毎月の計測値の変 動を調べるために，それぞれの変動係数を計算した。 項目間の変動の大きさを比較するために, summary coeffcient を使った．月齢ごとに比較すると，頭囲 の変動が他の項目に比べて一番小さかった．皮脂厚 の変動は比較的大きかった． 皮脂厚の絶対值と対数 変換值を比較すると, 対数変換值のほうが変動は小 さかった。

$$
\text { （高井省三 抄訳） }
$$

\section{References}

BHALLA, A.K., 1983: A longitudinal study of body growth of Punjabi children during the first year of life. Department of Anthropology, Panjab University, Chandigarh, pp.1-300.

BOYTON, B., 1936: The Physical Growth of Girls. 
University of Iowa Studies, Iowa.

BROZEK, J., 1956: Role of anthropometry in the study of body composition: Towards synthesis in methods. Annals of New York Academy of Sciences, 63: 491-504.

EDWARDS, D.A., W.H. HAMMOND, M.J.R. HEALY, J.M. TANNER and R.W. WHITEHOUSE, 1955:
Design and accuracy of caliper for measuring subcutaneous tissue thickness. Br. J. Nutr., 9: 133-143. JELLIFFE, D.B., and E.F.P. JELLIFFE, 1960: The prevalence of protein-calorie malnutrition of early childhood in Haiti. Am. J. Pub. Hlth., 50: 1355-1366. MEREDITH, H.V., 1935: The Rhythm of Physical Growth. University of Iowa Studies, Iowa.

A.K. Bhalla c/o Dr. B.N.S. WAliA, Department of Pediatrics, Post Graduate Institute of Medical Education and Research, Sector-12, Chandigarh-160012, India 